Maurice A. Deane School of Law at Hofstra University Scholarly Commons at Hofstra Law

Hofstra Law Faculty Scholarship

$10-2012$

\title{
Special Issue Introduction: Immigrants and The Family Court
}

Theo Liebmann

Maurice A. Deane School of Law at Hofstra University

Lauris Wren

Maurice A. Deane School of Law at Hofstra University

Follow this and additional works at: https://scholarlycommons.law.hofstra.edu/faculty_scholarship

\section{Recommended Citation}

Theo Liebmann and Lauris Wren, Special Issue Introduction: Immigrants and The Family Court, 50 Fam. Ct. Rev. 570 (2012) Available at: https://scholarlycommons.law.hofstra.edu/faculty_scholarship/743

This Article is brought to you for free and open access by Scholarly Commons at Hofstra Law. It has been accepted for inclusion in Hofstra Law Faculty Scholarship by an authorized administrator of Scholarly Commons at Hofstra Law. For more information, please contact lawcls@hofstra.edu. 


\title{
SPECIAL ISSUE INTRODUCTION: IMMIGRANTS AND THE FAMILY COURT
}

\author{
Theo Liebmann and Lauris Wren
}

Family courts throughout the United States have explicit statutory duties to aid families in crisis, to maintain families whenever appropriate, to protect children and safeguard their well-being, and to provide children with permanency in their lives. These are not narrow obligations, and the judges, practitioners, and agencies involved in family courts must constantly adapt to serve the individual needs of all the families that come before them. The purpose of this Special Issue is to examine the unique challenges presented by working with families and children who are immigrants - both documented and undocumented - and the complex interplay between immigration issues and the family court's obligations to serve the families and children who come before it.

As the number of authorized and unauthorized immigrants in the United States continues to rise, immigration issues increasingly permeate family court proceedings. When immigrant families become subject to a family court's jurisdiction, the court's services, its traditional "best interests" legal standard, and its rulings frequently must be considered and effectuated from a different perspective. Undocumented and permanent residents, for example, face potential severe consequences to family court findings with which citizens need not contend, such as detention in an immigration facility, deportation to another country, and permanent geographical separation from their families. These ramifications compound the challenges already faced by many families served by family courts. At the same time, family court involvement can sometimes create opportunities for immigration relief for the survivors of abuse, neglect, abandonment, and domestic violence whom the court serves.

In order to better understand the impact immigration issues are having in family courts, we conducted two informal surveys, one of family court judges around the United States and one of attorneys practicing in family courts. Overwhelmingly, the survey of the family court judges, which was completed by 109 judges throughout the United States, showed that immigration status and laws play a significant role in family court proceedings. ${ }^{2}$ Ninety-three percent of the judges had handled a case in which the immigration status of a party was raised as an issue. Immigration status became an issue most frequently in the context of custody and visitation, although also in division of property/allocation of support, guardianship, adoption, termination of parental rights, abuse/neglect, juvenile delinquency, child support, orders of protection, domestic violence, and criminal contexts. A stunning seventy-two percent of family court judges surveyed believed that their level of knowledge regarding immigration law was insufficient to resolve issues arising out of a party's immigration status.

The survey of family court attorneys showed similar results. Ninety-five percent of the attorneys had handled cases in which their client or the other party's immigration status was an issue, factor, or consideration in the family court action. Only fourteen percent of the attorneys believed that family court judges were knowledgeable in areas in which immigration law affects family court decisions. Fifty-three percent said the judges were not knowledgeable in these areas, and nearly thirty-five

Correspondence: theo.liebmann@hofstra.edu 
percent were unsure. Only seven percent of the attorneys believed that family court practitioners were knowledgeable in areas in which immigration law affects family court decisions.

The articles in this Special Issue highlight some of the most significant tensions and areas of interplay between family court proceedings and immigration issues.

- Sarah Rogerson's article Unintended and Unavoidable: The Failure to Protect Rule and Its Consequences for Undocumented Parents and Their Children incisively exposes how the application of the failure-to-protect rule by the child welfare system in mixed-immigration status families leads to further endangering children's safety and offers recommendations for ameliorating the problem.

- In 'Til Death Do Us Part: Affidavits of Support and Obligations to Immigrant Spouses, Veronica Thronson provides a detailed and thoughtful analysis on how affidavits of support in immigration proceedings impact future family court proceedings.

A trio of articles focuses on issues regarding unaccompanied immigrant youth, a rapidly increasing population: ${ }^{3}$

- In Disparate Outcomes: The Quest for Uniform Treatment of Immigrant Children, Randi Mandelbaum and Elissa Steglich explain how immigrant children are treated in vastly inconsistent manners depending on how they find themselves in family court and offer suggestions for increased uniformity to ensure that immigrant youth avail themselves of opportunities to achieve permanent legal status.

- Jennifer Baum, Alison Kamhi, and C. Mario Russell describe a number of disturbing gaps in how Special Immigrant Juvenile Status, one of the most compassionate provisions of federal immigration law, is being utilized to help immigrant youth, in Most in Need But Least Served: Legal and Practical Barriers to Special Immigrant Juvenile Status for Federally Detained Minors.

- In Sufren Los Niños: Exploring the Impact of Unauthorized Immigration Status on Children's Well-being, Jorge M. Chavez, Anayeli Lopez, Christine M. Englebrecht, and Ruben P. Viramontez Anguiano describe their own study, as well as prior research, on the impact of unauthorized status on the well-being of children in immigrant families.

Two articles discuss different ways that immigration concerns impact practical and ethical issues inherent in family court practice:

- Sara Elizabeth Dill brings to light the challenges that noncitizens have in accessing the diversion and therapeutic courts that are common in family and criminal courts in Unbalanced Scales of Justice: How ICE Is Preventing Noncitizens from Having Equal Access to Diversion Programs and Therapeutic Courts.

- In Ethical Advocacy for Immigrant Survivors of Family Crisis, we argue that ethical mandates related to client counseling, representational goals, and competence require family court practitioners to provide advice and advocacy related to collateral immigration benefits for survivors of family crisis.

Finally, this Special Issue ends with a crucial perspective on how immigrants are treated in family courts - the viewpoint of immigrant youth themselves - drawn from an interview by Hofstra Law Student Ashley Sauerhof of Lauren Burke, founder of the immigrant youth empowerment organization Atlas: DIY.

Coinciding with the release of this Special Issue, experts from around the country will be gathering at Hofstra Law School on November 9, 2012, for a symposium on Immigrants and the Family Court. The symposium will examine the vital and complex interplay of immigration issues and family court matters; explore the statutory and ethical obligations for judges, practitioners, and agencies that result 
from that interplay; and discuss ways that the family court can better serve immigrant youth and families. ${ }^{4}$ We hope this Special Issue will enlighten discussion at this upcoming Symposium.

We extend our heartfelt thanks to the wonderfully talented authors who devoted so much time and energy to their contributions to this Special Issue. And our thanks as well to the FCR staff and editorial board, and especially to our friend and colleague Andy Schepard, who enthusiastically endorsed the development of this Special Issue the very first time we broached the idea. Finally, we thank you, our readers, for taking the time to read the articles in this Special Issue. We hope that, like us, you find them thought provoking and useful as we all work to make our family courts better serve immigrant families and children. 


\section{APPENDIX}

\section{Family Court Judge Questionnaire}

1. Have you ever handled a case in which the immigration status of a party was raised as an issue?

\begin{tabular}{|c|c|c|c|c|}
\hline & & & $\begin{array}{c}\text { Response } \\
\text { Percent }\end{array}$ & $\begin{array}{c}\text { Response } \\
\text { Count }\end{array}$ \\
\hline a. Yes & $\square$ & $\square$ & $92.7 \%$ & 102 \\
\hline b. No & $\square$ & & $7.3 \%$ & 8 \\
\hline \multicolumn{4}{|c|}{ answered question } & 110 \\
\hline \multicolumn{4}{|c|}{ skipped question } & 0 \\
\hline
\end{tabular}

2. What is the most frequent context in which you see the issue of a party's immigration status come up?

\begin{tabular}{|c|c|c|c|}
\hline & & $\begin{array}{c}\text { Response } \\
\text { Percent }\end{array}$ & $\begin{array}{c}\text { Response } \\
\text { Count }\end{array}$ \\
\hline $\begin{array}{r}\text { a. Division of Property/Allocation } \\
\text { of Support }\end{array}$ & $\square$ & $4.7 \%$ & 5 \\
\hline b. Custody and Visitation & $\square$ & $51.9 \%$ & 55 \\
\hline c. Guardianship & $\square$ & $9.4 \%$ & 10 \\
\hline d. Adoption & $\square$ & $8.5 \%$ & 9 \\
\hline e. Termination of Parental Rights & $\square$ & $17.0 \%$ & 18 \\
\hline f. Abuse/Neglect & $\square$ & $37.7 \%$ & 40 \\
\hline g. Juvenile Delinquency & $\square$ & $22.6 \%$ & 24 \\
\hline h. Child Support & $\square$ & $11.3 \%$ & 12 \\
\hline \multirow[t]{3}{*}{ Other (please specify) } & $\square$ & $22.6 \%$ & 24 \\
\hline & & answered question & 106 \\
\hline & & skipped question & 4 \\
\hline
\end{tabular}


3. How frequently do you handle cases in which the immigration status of one of the parties becomes an issue?

\begin{tabular}{|c|c|c|c|}
\hline & & $\begin{array}{c}\text { Response } \\
\text { Percent }\end{array}$ & $\begin{array}{l}\text { Response } \\
\text { Count }\end{array}$ \\
\hline a. More than once a week & $\square$ & $8.3 \%$ & 9 \\
\hline $\begin{array}{r}\text { b. More than once a month but less } \\
\text { then once a week }\end{array}$ & $\square$ & $27.8 \%$ & 30 \\
\hline $\begin{array}{r}\text { c. More than once a year but less } \\
\text { than once a month }\end{array}$ & $\square$ & $45.4 \%$ & 49 \\
\hline d. Less than once a year & $\square$ & $13.9 \%$ & 15 \\
\hline \multirow[t]{3}{*}{ e. Never } & $\square$ & $4.6 \%$ & 5 \\
\hline & & answered question & 108 \\
\hline & & skipped question & 2 \\
\hline
\end{tabular}

4. When you handle cases in which the immigration status of a party becomes an issue, how often is that status a factor in your final decision?

\begin{tabular}{|c|c|c|c|}
\hline & & $\begin{array}{c}\text { Response } \\
\text { Percent }\end{array}$ & $\begin{array}{c}\text { Response } \\
\text { Count }\end{array}$ \\
\hline a. Often & $\square$ & $16.0 \%$ & 17 \\
\hline b. Sometimes & $\square$ & $31.1 \%$ & 33 \\
\hline c. Rarely & $\square$ & $36.8 \%$ & 39 \\
\hline \multirow[t]{3}{*}{ d. Never } & $\square$ & $16.0 \%$ & 17 \\
\hline & & answered question & 106 \\
\hline & & skipped question & 4 \\
\hline
\end{tabular}


5. Are you satisfied that the level of knowledge you have regarding immigration law is sufficient to resolve issues arising out of a party's immigration status?

\begin{tabular}{|c|c|c|c|}
\hline & & $\begin{array}{c}\text { Response } \\
\text { Percent }\end{array}$ & $\begin{array}{c}\text { Response } \\
\text { Count }\end{array}$ \\
\hline a. Yes & $\square$ & $27.6 \%$ & 29 \\
\hline b. No & $\square$ & $72.4 \%$ & 76 \\
\hline \multicolumn{3}{|c|}{ answered question } & 105 \\
\hline \multicolumn{3}{|c|}{ skipped question } & 5 \\
\hline
\end{tabular}

\section{How would you suggest that courts improve how they handle the issue of immigration} status in the family law context?

\section{Response Response \\ Percent Count}

a. Training of Family Court judges in key areas of immigration law

b. Training of Family Court lawyers in key areas of immigration law

$\square+14.2 \%$

$13.2 \%$

c. Creating a manual that explains key areas of immigration law and how they intersect with the major areas of family law

d. All of the above

$67.9 \%$

Other (please specify)

$5.7 \%$ 


\section{Family Court Lawyer Questionnaire}

1. Have you ever handled a case where your client's (or the other party's) immigration status was an issue, factor, or consideration in the Family Court action?

\begin{tabular}{|c|c|c|c|}
\hline & & $\begin{array}{c}\text { Response } \\
\text { Percent }\end{array}$ & $\begin{array}{c}\text { Response } \\
\text { Count }\end{array}$ \\
\hline a. Yes & 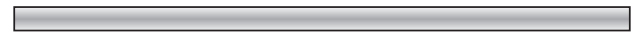 & $95.3 \%$ & 41 \\
\hline b. No & $\square$ & $4.7 \%$ & 2 \\
\hline \multicolumn{3}{|c|}{ answered question } & 43 \\
\hline \multicolumn{3}{|c|}{ skipped question } & 0 \\
\hline
\end{tabular}

2. What is the most frequent context in which you see the issue of a party's immigration status come up?

\begin{tabular}{|c|c|c|c|}
\hline & & $\begin{array}{c}\text { Response } \\
\text { Percent }\end{array}$ & $\begin{array}{c}\text { Response } \\
\text { Count }\end{array}$ \\
\hline a. Divorce proceedings & $\square$ & $11.6 \%$ & 5 \\
\hline $\begin{array}{r}\text { b. Allocation of Property and } \\
\text { Support }\end{array}$ & $\square$ & $9.3 \%$ & 4 \\
\hline c. Child Custody Determinations & $\square$ & $34.9 \%$ & 15 \\
\hline d. Termination of Parental Rights & $\square$ & $16.3 \%$ & 7 \\
\hline e. Special Immigrant Juvenile & $\square$ & $37.2 \%$ & 16 \\
\hline \multirow[t]{3}{*}{ Other (please specify) } & $\square$ & $30.2 \%$ & 13 \\
\hline & & answered question & 43 \\
\hline & & skipped question & 0 \\
\hline
\end{tabular}


3. How frequently do you handle cases in which the immigration status of one of the parties becomes an issue?

\begin{tabular}{|c|c|c|c|}
\hline & & $\begin{array}{l}\text { Response } \\
\text { Percent }\end{array}$ & $\begin{array}{c}\text { Response } \\
\text { Count }\end{array}$ \\
\hline a. Once a week & $\square$ & $25.6 \%$ & 11 \\
\hline b. Once a month & $\square$ & $37.2 \%$ & 16 \\
\hline c. Once a year & $\square$ & $2.3 \%$ & 1 \\
\hline \multirow[t]{4}{*}{$\begin{array}{r}\text { d. Occasionally, but not on a } \\
\text { regular basis }\end{array}$} & $\square$ & $37.2 \%$ & 16 \\
\hline & $\square$ & $2.3 \%$ & 1 \\
\hline & & answered question & 43 \\
\hline & & skipped question & 0 \\
\hline
\end{tabular}

4. In cases where immigration status becomes an issue, how often does that status appear to affect the decision of the Judge?

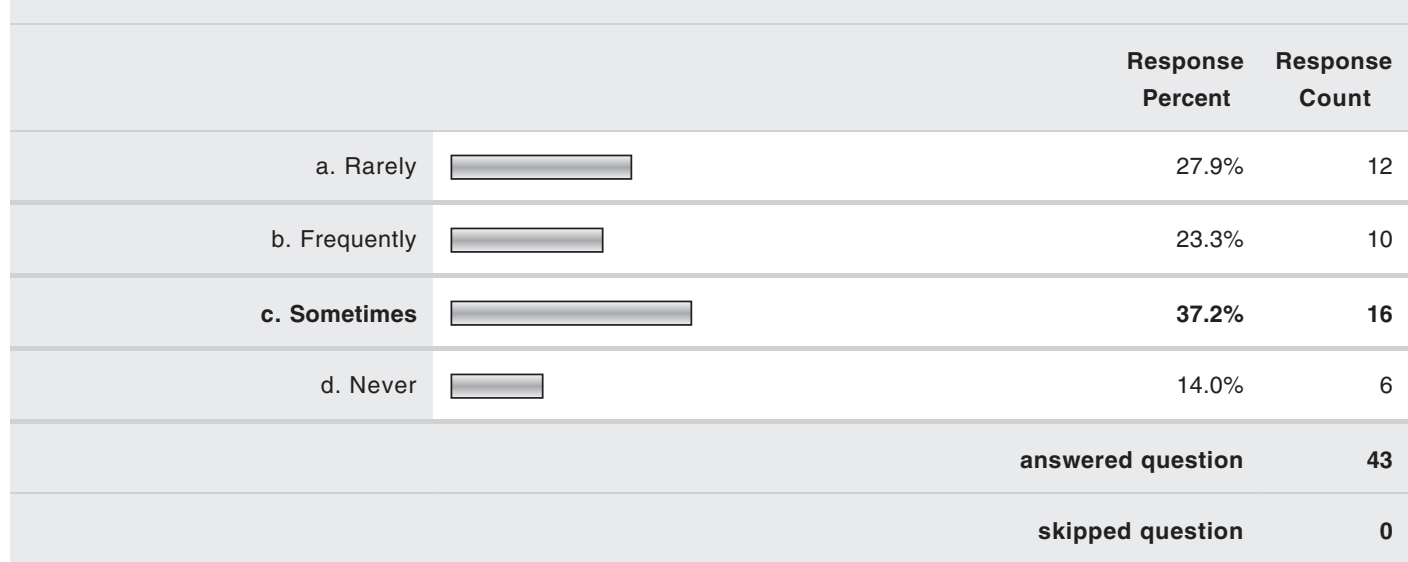


5. Do you believe Family Court judges are knowledgeable in areas in which immigration law affects Family Court decisions?

\begin{tabular}{|c|c|c|c|}
\hline & & $\begin{array}{c}\text { Response } \\
\text { Percent }\end{array}$ & $\begin{array}{c}\text { Response } \\
\text { Count }\end{array}$ \\
\hline a. Yes & $\square$ & $14.0 \%$ & 6 \\
\hline b. No & $\square$ & $53.5 \%$ & 23 \\
\hline \multirow[t]{3}{*}{ c. Unsure } & $\square$ & $34.9 \%$ & 15 \\
\hline & & answered question & 43 \\
\hline & & skipped question & 0 \\
\hline
\end{tabular}

6. Do you believe that Family Court attorneys are knowledgeable in areas in which immigration law affects Family Court decisions?

\begin{tabular}{rrrr} 
& & $\begin{array}{r}\text { Response } \\
\text { Percent }\end{array}$ & $\begin{array}{c}\text { Response } \\
\text { Count }\end{array}$ \\
a. Yes & $7.1 \%$ & 3 \\
b. No & & $66.7 \%$ & 28 \\
\hline c. Unsure & & $31.0 \%$ & 13 \\
& & answered question & 42 \\
& & skipped question & 1
\end{tabular}




\begin{tabular}{|c|c|c|c|}
\hline & & $\begin{array}{c}\text { Response } \\
\text { Percent }\end{array}$ & $\begin{array}{c}\text { Response } \\
\text { Count }\end{array}$ \\
\hline $\begin{array}{l}\text { a. Training of Family Court judges } \\
\text { in key areas of immigration law. }\end{array}$ & $\square$ & $18.6 \%$ & 8 \\
\hline $\begin{array}{l}\text { b. Training of Family Court lawyers } \\
\text { in key areas of immigration law. }\end{array}$ & $\square$ & $20.9 \%$ & 9 \\
\hline $\begin{array}{r}\text { c. Creating a manual that explains } \\
\text { key areas of immigration law and } \\
\text { how they intersect with the major } \\
\text { areas of family law. }\end{array}$ & $\square$ & $20.9 \%$ & 9 \\
\hline d. All of the above. & $\square$ & $76.7 \%$ & 33 \\
\hline \multirow[t]{3}{*}{ Other (please specify) } & $\square$ & $7.0 \%$ & 3 \\
\hline & & d question & 43 \\
\hline & & d question & 0 \\
\hline
\end{tabular}

\section{NOTES}

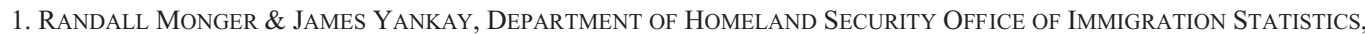
ANNUAl Flow REPORT: U.S. LEgAl PERMANENT RESIDENTS: 2010 (March 2011) (over one million new immigrants obtained permanent legal status in 2010); Michael HofFER ET AL., DEPARTMENT OF HOMELAND SECURITY OfFICE Of IMMIGRATION

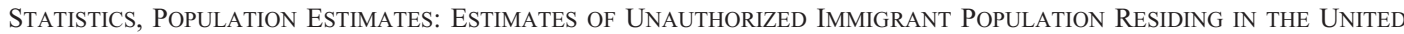
STATES: JANUARY 2010 (February 2011) (population of unauthorized immigrants in 2010 estimated at nearly eleven million).

2. This survey and a summary of the results of the survey are attached as an appendix to this introduction. The judicial survey was distributed to judges through the National Council of Juvenile and Family Court Judges, and the attorney survey was distributed to a list of New York and national family court practitioners compiled by Hofstra's Center for Children, Families and the Law.

3. From October 2011 through March 2012, over five thousand unauthorized immigrant children came into U.S. custody without a parent or guardian - a ninety-three percent increase from the same period the previous year. Associated Press, Unprecedented Surge in Unaccompanied Child Immigrants Puts Stress on Federal Support System, WASH. Post, Apr. 28, 2012.

4. Just as family law attorneys would benefit from a more in-depth understanding of immigration law, immigration attorneys would also benefit from a more in-depth understanding of family law. The topics are intricately linked; a major goal of our immigration laws is family reunification, and the vast majority of immigrants to the United States immigrate through family-based immigration visas. Immigration petitions - and removals from the United States - may depend on family court findings and adjudications. A training focused more deeply on family law for immigration attorneys is, however, beyond the scope of this publication and symposium. 